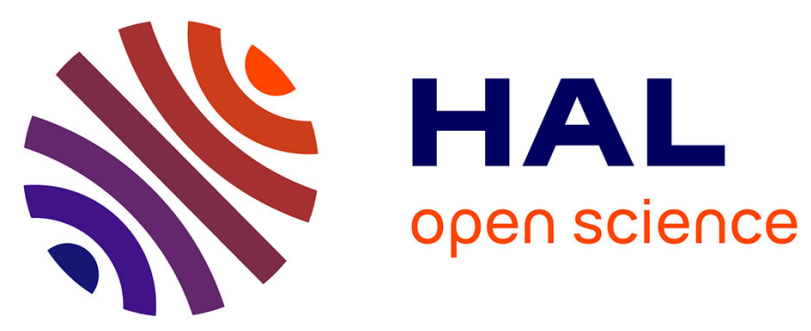

\title{
Trophic resource partitioning within a shorebird community feeding on intertidal mudflat habitats
}

Pierrick Bocher, Frédéric Robin, Jessica Kojadinovic, Philippe Delaporte, Pierre Rousseau, Christine Dupuy, Paco Bustamante

\section{To cite this version:}

Pierrick Bocher, Frédéric Robin, Jessica Kojadinovic, Philippe Delaporte, Pierre Rousseau, et al.. Trophic resource partitioning within a shorebird community feeding on intertidal mudflat habitats. Journal of Sea Research (JSR), 2014, 92, pp.115-124. 10.1016/j.seares.2014.02.011 . hal-01072993

\section{HAL Id: hal-01072993 https://hal.science/hal-01072993}

Submitted on 8 Oct 2014

HAL is a multi-disciplinary open access archive for the deposit and dissemination of scientific research documents, whether they are published or not. The documents may come from teaching and research institutions in France or abroad, or from public or private research centers.
L'archive ouverte pluridisciplinaire HAL, est destinée au dépôt et à la diffusion de documents scientifiques de niveau recherche, publiés ou non, émanant des établissements d'enseignement et de recherche français ou étrangers, des laboratoires publics ou privés. 


\section{Trophic resource partitioning within a shorebird community feeding on intertidal mudflat habitats}

Pierrick Bocher $^{a^{*}}$, Frédéric Robin $^{\mathrm{a}}$, Jessica Kojadinovic ${ }^{\mathrm{a}}$, Philippe Delaporte ${ }^{\mathrm{b}}$, Pierre Rousseau $^{\mathrm{b}}$, Christine Dupuy $^{\mathrm{a}}$, Paco Bustamante $^{\mathrm{a}}$

${ }^{a}$ Laboratory Littoral Environnement et Sociétés, UMR7266 LIENSs, CNRS - University of La Rochelle, La Rochelle 17042, France.

${ }^{b}$ Réserve Naturelle Nationale de Moëze-Oléron, Ligue pour la Protection des Oiseaux, Plaisance, 17180 Saint-Froult, France.

Corresponding author: UMR 7266 LIESss CNRS-University of La Rochelle, 2 rue Olympe de Gouges, 17000 La Rochelle, France Tel: +33 5454682 92; Fax: + $3354546826 a$; Email: pbocher@univ-lr.fr

\section{ABSTRACT}

In ecological systems, it is necessary to describe the trophic niches of species and their segregation or overlap to understand the distribution of species in the community. In oceanic systems, the community structure of top predators such as seabird communities has been well documented with many studies in several biogeographical areas. But for coastal habitats, very few investigations on the trophic structure have been carried out in avian communities. In this study, the trophic resource partitioning was investigated on eight of the most abundant species of a shorebird community on the central Atlantic coast of France. Our work comprised a comprehensive sample of birds with different ecomorphogical patterns and data on their main prey to encompass potential sources of overlap and segregation in this community. We examined the stable carbon $\left(\delta^{13} \mathrm{C}\right)$ and nitrogen $\left(\delta^{15} \mathrm{~N}\right)$ isotopic composition of blood to investigate the trophic structure (1) on a temporal scale by comparing migration and wintering periods; (2) on a spatial scale through inter-site comparisons; and (3) on the community level 
within groups of phylogenetically related species. Diets appeared different in several cases between periods, between sites and between juveniles and adults for the same sites. A clear trophic partitioning was established with four functional groups of predators in winter inside the community. The Grey Plover, the Bar-tailed Godwit, the Curlew and a majority of the dunlins were worms-eater mainly feeding on Nereis diversicolor or Nephtys hombergii Two species were predominantly deposit-suspensivorous mollusc-eaters, including the Red Knot and the Black-tailed Godwit feeding mainly on Macoma balthica. The Oystercatcher fed mainly on suspensivorous molluscs like Cerastodrema edule and two species including the Redshank and some dunlins adopted opportunistic behaviours feeding on mudflat and/or in marshes.

KEYWORDS: trophic level, $\delta^{15} N, \delta^{13} C$, isotopic niches, mudflat ecosystem, Scolopacidae, Charadriidae

\section{Introduction}

Predator-prey relationships and their dynamics in space and time are among the fundamental basis of the structure of animal communities and their evolution (Paine, 1980). Numerous theoretical models have attempted to define different aspects of food webs and their implications in the stability, complexity, connectivity and equilibrium of communities' parameters (Fussmann and Heber, 2002). In order to understand the distribution of species in the community (e.g. Myers and Worm, 2003) it is necessary to describe the trophic niches of species and their segregation or overlap, as well as parameters including species richness, relative abundance and spatial or temporal variations. Previous studies have emphasized that the overlap in the diets of different organisms with possible intra- and interspecific competition for food influences the variation in composition of species in communities 
(Werner and Gilliam, 1984; Forero et al., 2004; Aguilera and Navarrete, 2011). Progress in this domain is however restricted as it is difficult to deliver empirical evidence supporting theoretical developments in community ecology, especially for marine systems.

In marine systems, the structure of seabird communities established from specific trophic niches' comparison has been well documented from birds caught during their breeding season (e.g. Forero et al., 2004; Bearhop et al., 2006; Kojadinovic et al., 2008; Cherel et al., 2008; Jeager et al., 2010; Phillips et al., 2011). But for shorebird communities very few investigations on the trophic interactions between predators on intertidal mudflat have been carried out. Most shorebird species are predators specialized on intertidal mudflat habitats during the non-breeding period (van de Kam et al., 2004; Colwell, 2010). On the Western European coastline birds arrive in late summer-early autumn from their breeding sites in Northern Europe or Arctic latitudes, and part of them stay during the entire winter period on coastal wetlands (Delany et al., 2009). Other populations use the same sites only as stopovers coming back from breeding sites in autumn or on route from wintering area from Africa in spring (van de Kam et al., 2004; Delany et al., 2009). A dozen of species are common on the coast of Western Europe and forage exclusively or regularly on intertidal mudflat according to tidal rhythms (van de Kam et al., 2004). Shorebirds commonly aggregate in dense, mixedspecies flocks feeding on the same areas (Burger et al., 1979; Metcalfe et al., 1989). They feed on benthic prey from macrofauna communities (Yates et al., 1993; Zwarts et al., 1993; Meire et al., 1994) and smaller species may also ingest biofilm and microfauna (Kuwae et al., 2012). The mechanisms by which species of shorebirds are segregated should involve the combination of diet, feeding area, feeding methods and behaviour (Baker and Baker, 1973). Moreover, differences in bill morphologies and sizes inside the community of shorebirds are adapted for feeding on a subset of potential prey and should avoid competition. The functional 
relationships between bill morphology and diet should lead to specialization on a limited array of prey species (Nebel, 2005; Nebel, 2011). Species should differ in selection of prey of different sizes, with larger-bodied species feeding on larger prey of wider size range and small-bodied species feeding on smaller prey with less variability in their selection.

Different methods such as stomach content or faeces analysis have previously been used to describe the diet and consequently contribute to define the trophic niche (Colwell, 2010). But these methods, while they can give high degree of precision on prey type and size, are nevertheless time consuming and can thus not be applied to a high number of individuals. An alternative and complementary approach to these methods is the measurement of naturally occurring stable isotopes in consumers and their prey (Layman et al., 2012). The principle underlying this approach is that stable isotope deviations of nitrogen and carbon in consumers reflect those of their prey as they are enriched in a predictable manner. Conventionally expressed as $\delta^{15} \mathrm{~N}(\%)$, the deviation of ${ }^{15} \mathrm{~N}$ to ${ }^{14} \mathrm{~N}$ generally exhibits a stepwise enrichment from 2 to $5 \%$ relative to dietary nitrogen (Kelly, 2000). This discrepancy of $\delta^{15} \mathrm{~N}$ is caused by a selective retention of the heavy isotope and excretion of the light one. It provides a tool for comparing the relative trophic level of various consumers living in the same environment. The deviation of ${ }^{13} \mathrm{C}$ to ${ }^{12} \mathrm{C}$ (denoted as $\delta^{13} \mathrm{C}$ ) is also enriched with respect to dietary carbon, but to a much lesser degree than $\delta^{15} \mathrm{~N}$, on the order of $1 \%$ (DeNiro and Epstein, 1978). Stable isotope deviations also have the advantage of offering information on a larger time scale according to the isotopic turnover rates of the considered tissue, $\delta^{15} \mathrm{~N}$ and $\delta^{13} \mathrm{C}$ measurements of multiple tissues providing dietary information on several days to several weeks (Hobson and Clark, 1992).

In this study, the trophic resource partitioning in a shorebird community was investigated on the central Atlantic coast of France. On the same sites, previous diet 
investigations on Red Knot Calidris canutus (Quaintenne et al., 2010) and Black-tailed Godwit Limosa limosa (Robin et al., 2013) revealed a high degree of specialization on a low number of prey species. However, the number of species foraging at the same time on a same mudflat could be high, and relationships among them are unknown and poorly studied for shorebirds. Our work comprised a comprehensive sample of shorebirds and their main prey to encompass potential sources of overlap and segregation in the community. Our overall objective was to describe the trophic structure of a complex assemblage of shorebirds at different scales and determine the degree of ecological overlap/segregation among species. More specifically, we investigated the trophic structure at multiple scales: (1) temporal in comparing migration and wintering; (2) spatial by inter-site comparison; and (3) among individuals and species within the same temporal and spatial conditions.

\section{Materials and methods}

\subsection{Study sites and periods}

The Pertuis Charentais, on the French Atlantic coast, are shallow coastal embayments formed by the islands of Oléron and Ré (Fig. 1). Protected by these offshore islands, the coastline is constituted of a series of muddy estuaries and bays followed by dyked-up polders and marshes reclaimed from the saltmarshes. The local wintering shorebird populations were studied at three sites (Fig. 1): on Ré Island $\left(46^{\circ} 13^{\prime} \mathrm{N} ; 1^{\circ} 30^{\prime} \mathrm{W}\right)$ with c. 23,000 individuals for 20 species counted in mid-January 2010 in Yves Bay $\left(46^{\circ} 02^{\prime} \mathrm{N} ; 01^{\circ} 03^{\prime} \mathrm{W}\right)$ with c. 10,000 individuals for 14 species; and on the main study sites of the Marennes-Oléron Bay, $\left(45^{\circ} 53^{\prime} \mathrm{N}\right.$; $1^{\circ} 05^{\prime} \mathrm{W}$ ) with c. 67,000 individuals for 18 species (Caillot and Elder, 2000-2010; Mahéo, 2011). The study was carried out only during the non-breeding period and precisely during the post-breeding migration designated as the autumn stage (July to September) and the winter 
stage (October to March). Very few shorebirds breed in France and almost all the individuals in the Pertuis Charentais come from northern Europe, Siberia, Greenland or Arctic Canada after their breeding stage (Delany et al., 2009). During autumn individuals migrating toward the African coast or southern Europe can mix with local wintering residents. The pre-breeding migration occurs in April and May for most of the species but some individuals of some species can stay locally during the stopover in March when coming from Africa or Iberia (Delaporte Pers.Com.). The birds were sampled in three different sites, distant from each other by only a few tens of kilometres but comprising distinct mudflat habitat characteristics. The sites of Moëze and Yves are bare mudflats with soft sediment in Moëze and a gradient of sandy to muddy sediment in Yves Bay (Bocher et al., 2007). In Ré island, on the intertidal area of the bay where most of the shorebirds forage, the mudflat is covered with a seagrass bed of Zostera noltii.

\subsection{Capture and Sampling}

Shorebirds were caught in mist-nets on high tide roosts during non-moonlit nights from February 2007 to November 2009. However, $68 \%$ of the individuals sampled was caught at the roost in the Moëze marshes in the Marennes-Oléron Bay (Table 1). At the two other sites, the capture effort was concentrated between September and November 2007 or 2008. The number of individuals sampled per species, per site and per season depended on catching success and field facilities for sampling blood on birds in safe conditions. In this study, we retained only species most successfully caught and listed among the ten most common species in the Pertuis Charentais. These species were, from the smallest (c. $45 \mathrm{~g}$ ) to the largest (c. 750g): Dunlin Calidris alpina, Redshank Tringa totanus, Red Knot Calidris canutus, Grey Plover Pluvialis squatarola, Bar-tailed Godwit Limosa lapponica, Black-tailed Godwit Limosa limosa, Oystercatcher Haematopus ostralegus and Curlew Numenius arquata (Table 
1). Feathers and whole blood were sampled from randomly selected birds, after which the birds were immediately released (Table 1). Juveniles (JUV) considered as the individuals between their birth and the second moult in autumn were distinguished from adults (AD) using isotopic signatures in wing feathers (Atkinson et al., 2005, Bocher et al., 2012). It was however not possible to sex all individuals according to biometric or plumage characteristics. The most common and abundant benthic invertebrate species and the microphytobenthos of adjacent tidal mudflat of Moëze marshes (main catch site) were collected on two stations at high and medium intertidal levels in February 2008. Terrestrial invertebrates were collected in Moëze marshes in March 2008. All the species were considered as potential prey for birds (van de Kam et al., 2004) and their isotopic signatures were established to provide values of food sources.

\subsection{Stable isotope analysis and methodological considerations}

Tissue sampling - The stable isotope analyses were performed on $1 \mathrm{~cm}^{2}$ of the sixth primary feather cover and less than $300 \mu \mathrm{L}$ of whole blood. Feathers are metabolically inert and for many long-distance migrants, this feather is moulted at the same time as the primaries (Hobson and Clark, 1992) and its isotope content is thus likely to be indicative of the post breeding moult area for adults (wintering grounds) or exclusively the breeding area for first winter birds (Atkinson et al., 2005). In this study, feather signatures were only used to certify age of individuals and origin of birds coming from Africa during migration. Blood was extracted from the right jugular and kept in $75 \%$ ethanol. The entire blood sample was used (plasma + cells) and provided an indication on the diet according to an integrated signal over a time window of at least 20 days as described for the Dunlin Calidris alpina by Ogden (2004). 
In the laboratory - Feathers were washed to remove oil and dirt in a chloroform-methanol solution (2:1) in an ultrasonic bath for two minutes. Afterwards, they were rinsed in two consecutive pure methanol baths for a few seconds and dried at $40{ }^{\circ} \mathrm{C}$ for 48 hours. Each sample was then chopped using surgical scissors and accurately weighed out to between 0.3 and $0.4 \mathrm{mg}$. Whole blood stored in $75 \%$ ethanol was simply dried to obtain a powder. The samples were precisely weighed $( \pm 0.001 \mathrm{mg})$ in a tin capsule for stable isotope analysis and were analyzed using an elemental analyzer (Flash EA 1112 fitted with a "No Blank" option, Thermo Scientific, Milan, Italy) coupled to an isotope ratio mass spectrometer (Delta V Advantage with a Conflo IV interface, Thermo Scientific, Bremen, Germany). The results are reported as per mil (\%o) and are expressed in the $\delta$ unit notation as deviations from standards (Vienna Pee Dee Belemnite for $\delta^{13} \mathrm{C}$ and $\mathrm{N}^{2}$ in air for $\delta^{15} \mathrm{~N}$ ) following the formula: $\delta$ isotope $=\left(\frac{R_{\text {sample }}}{R_{\text {standard }}}-1\right) * 1000$, where $\delta$ isotope is the sample ratio $\left({ }^{13} \mathrm{C}\right.$ or $\left.{ }^{15} \mathrm{~N}\right)$ relative to a standard (traceable to a primary international standard), and $R$ is the ratio of heavy to light isotope $\left({ }^{13} \mathrm{C} /{ }^{12} \mathrm{C}\right.$ or $\left.{ }^{15} \mathrm{~N} /{ }^{14} \mathrm{~N}\right)$ in the sample or standard. $\delta^{13} \mathrm{C}$ and $\delta^{15} \mathrm{~N}$ are reported relative to their primary international standards. The analytical precision of the measurements was $<0.06 \%$ and $<0.1 \%$ for carbon and nitrogen, respectively. In the analysis, $\delta^{13} \mathrm{C}$ and $\delta^{15} \mathrm{~N}$ were expressed as mean \pm SD. Most common and abundant tidal and marsh macro invertebrates for the Moëze site were collected by sieving the sediment in the field and were kept alive for 36 hours in filtered seawater to allow gut content evacuation, before storage at $20^{\circ} \mathrm{C}$ or $-80^{\circ} \mathrm{C}$. They were treated following the same method as for blood samples. After drying and crushing; when necessary, samples were acidified to remove carbonates. The isotopic signatures are listed in Table 2.

\subsection{Isotopic niches}


The isotopic niche positions were examined following Turner et al. (2010). This approach is developed on the convex hull metrics first described by Layman et al. (2007). According to Turner et al. (2010), we used nested linear models and residual permutation procedures to create and compare measures of central tendency for each population. The isotopic niche locations are considered to be different if the Euclidean distance between the two species is significantly greater than zero. $P$-values of metrics comparisons were obtained running $\mathrm{R}$ script from Turner et al. (2010) in Ecological Archives E091-157-S1.

\subsection{Statistics}

Differences between situations (Species, site, age and season) were analyzed by Nested PERMANOVAs for each factor with species nested in site and using unrestricted permutations of data with 9999 permutations, followed by a Barlett test pairwise comparisons if significant differences were detected among treatments. Statistical tests were performed with R software. Values are means \pm SD.

\section{Results}

\subsection{Individual values per species}

Considering the results for the 550 individuals sampled from the eight species during the complete study period (July-March), all the blood $\delta^{15} \mathrm{~N}$ values were comprised between 3.0\%o and $17.0 \%$ and the blood $\delta^{13} \mathrm{C}$ values were comprised between $-28.0 \%$ and $-8.0 \%$ (Fig. 2). However, most of the individuals' values in winter were restricted to narrower ranges, between $10.0 \%$ and $17.0 \%$ for $\delta^{15} \mathrm{~N}$ and $-17.0 \%$ and $-8.0 \%$ for $\delta^{13} \mathrm{C}$ for the Grey Plover Pluvialis squatarola, the Dunlin Calidris alpina, the Red Knot Calidris canutus, the Blacktailed Godwit Limosa limosa, the Bar-tailed Godwit Limosa lapponica and the Curlew Numenius arquata. For these six species in winter, exceptions appeared only for some $P$. 
Squatarola individuals at Yves and C. alpina individuals at Moëze with clear lower values for both elements. In autumn, for these six species, the isotopic values were broadly distributed between minimal values of $\delta^{15} \mathrm{~N}$ and $\delta^{13} \mathrm{C}$ and their maximal values recorded in winter. For the Oystercatcher Haematopus ostralegus, the winter but also the autumn values were all restricted to narrow ranges for $\delta^{15} \mathrm{~N}$ (between 10\%o to $14 \%$ ) and for $\delta^{13} \mathrm{C}$ (between $-19 \%$ and -13\%o). The Redshank Tringa totanus had a completely different distribution of the isotopic values which were distributed throughout large ranges compared to the others species. Some individuals displayed isotopic signatures with low values of $\delta^{15} \mathrm{~N}$ (down to $10 \%$ ) and with high values of $\delta^{13} \mathrm{C}$ (up to $-8 \%$ ) never met for the other species.

\subsection{Inter-factor comparisons}

Significant inter-specific differences in $\delta^{13} \mathrm{C}$ or $\delta^{15} \mathrm{~N}$ within shorebirds of the Pertuis Charentais were recorded (Table 2) when considering species nested in site, every site for all ages and between the two seasons. The nested PERMANOVA performed for all shorebird species showed that $\delta^{13} \mathrm{C}$ and $\delta^{15} \mathrm{~N}$ signatures were strongly influenced by all the factors (Table 2). Overall, the interactions between several factors were significant with the site factor for $\delta^{13} \mathrm{C}$ but with influences of age when combined with others factors. For $\delta^{15} \mathrm{~N}$ values, the Age factor appear as the less discriminant factor but only when combine with others factors and especially with species nested in site with no significant differences (Table 2).

\subsection{Inter- and intra-specific niche comparisons in winter}

Considering that in autumn, the isotopic signatures were highly variable because of the movements of the migrating individuals, trophic comparisons of the eight species were particularly focused on the winter season at Moëze where the highest number of birds was 
sampled. However, no H. ostralegus individuals had been caught in Moëze, so those of Yves were used for comparison. The mean stable nitrogen and carbon isotopic values for the eight shorebirds species are presented in Appendix A with the mean values of the most abundant marine (mudflat) and terrestrial (marshes) invertebrates considered as potential prey. $C$. alpina individuals in winter were clearly and visually divided in two groups in Figure 2 according to their $\delta^{13} \mathrm{C}$ values. Consequently, this species was divided in two sets: CALPALP1 with the individuals having $\delta^{13} \mathrm{C}<-17 \%$ and CALPAP2 with the individuals above this value (Table 2). For T. totanus, most of the birds were caught in March and some of them were identified as individuals coming from Africa according to the isotopic signatures in their feathers. These individuals were therefore subsequently excluded for mean calculation considering the probability that they had just arrived from remote wintering areas.

Four species: $N$. arquata, L. lapponica, P. squatarola and C. alpina (CALALP2) had very close mean isotopic signatures with the highest values among all shorebirds and invertebrates species (Fig. 3). The mean $\delta^{13} \mathrm{C}$ and $\delta^{15} \mathrm{~N}$ values for these four species were not significantly different (post-hoc Tuckey test, all $\mathrm{p}<0.005$ ) and the isotopic niches of the four species overlapped widely (Figs. 4a and 4b). The distance in mean centroïd location (MD) between each pair of the N. arquata, L. lapponica and P. squatarola did not differ significantly from zero (all $\mathrm{p}>0.5$ ), suggesting that species had a similar position in isotopic space. C. alpina (CALALP2) did not differ significantly in MD position only with P. squatarola $(\mathrm{p}=0.230$ ). The species L. limosa and C. canutus had lower $\delta^{15} \mathrm{~N}$ values, but values for $\delta^{13} \mathrm{C}$ remained close to those of the four previously cited species. There was a larger variation in $\delta^{15} \mathrm{~N}$ signatures for L. limosa than for C. canutus and niche locations were significantly different (p $<0.001)$. C. canutus was located at the same level as polychaete worms such as Nepthys hombergii or Nereis diversicolor. The niche MD comparison between $T$. totanus and $H$. 
ostralegus was the only other comparison with no significant difference $(\mathrm{p}=0.800)$ out of the set of the first three cited species and $C$. alpina (CALALP2) vs P. squatarola. Both species had lower $\delta^{15} \mathrm{~N}$ values than these four species and lower $\delta^{13} \mathrm{C}$ values than the other species except C. alpina (CALALP1). C. alpina (CALALP1) appeared isolated from the other species with clearly the lowest values in carbon but also with large intra-specific variation (Figs. 3 and 4).

Among invertebrates, the shrimp Crangon crangon had the highest trophic position. All the worms had similar signatures displaying high values of $\delta^{15} \mathrm{~N}$ and $\delta^{13} \mathrm{C}$ (Fig. 3). The depositsuspension feeding bivalves Scrobicularia plana, Macoma balthica and Abra tenuis with the gastropod Hydrobia ulvae formed another group of species with close $\delta^{13} \mathrm{C}$ values but with lower $\delta^{15} \mathrm{~N}$ values than the previous cited species. Both strict suspension feeding bivalves Cerastoderma edule and Ruditapes philippinarum had close signatures with much lower $\delta^{13} \mathrm{C}$ values. Among potential prey on intertidal mudflat, the microphytobenthos, mainly made of unicellular algae, was at the base of the food web with clearly the lowest $\delta^{15} \mathrm{~N}$ values; near 7\%.The terrestrial invertebrates were clearly distinct from all marine invertebrates with very low $\delta^{13} \mathrm{C}$ signatures, below the value of $-22 \%$.

\section{Discussion}

Specific studies on feeding ecology of shorebirds are common and especially for very well studied species like the Red Knot (Piersma and van Gils, 2011) or the Oystercatcher (Blomert et al., 1996). Nevertheless, they are rare at the level of the community and comparisons of trophic niches are often limited to habitat selection by visual observations on the field (e.g. Colwell, 1993; de Boer, 2002; Lopes et al., 2005; Jing et al., 2007). To the best of our knowledge, this study is the first comparison attempt focusing on the trophic niches of eight 
shorebird species and resource partitioning based on isotopic signatures in blood with more than 500 sampled individuals.

The multivariate analysis of all the data showed a strong effect of season, age and species on both isotope element signatures. Interactions between factors were not easy to discriminate but the site does not appear as the most discriminating factor when combined with others. The limited sample sizes for some combination of factors could limit the possibilities of comparisons. Nevertheless, differences between seasons could be clearly due to the early arriving of some individuals in August or September with isotopic signatures corresponding to prey collected on previous stopover sites on their migration route.

Differences in isotopic signatures between juveniles and adults are largely variable in all intra-site and intra-season comparisons. When differences were significant the adults always had higher mean isotopic values than the juveniles. Morphologically, juveniles tend to be smaller than adults and their bills are shorter (Cramp and Simmons, 1983). Furthermore, they are inexperienced when arriving for the first time on wintering sites. Consequently, it is expected that juveniles would specialize on a smaller and more easily manipulated variety of prey than adults (Puttick, 1978; Goss-Custard and Le V. dit Durell, 1983; Fasola et al., 1996). This difference in foraging ability may cause juveniles to specialise on different prey types or different feeding methods from adults (Le V. dit Durell, 2000). Moreover, juveniles could be subdominant to adults and thus often be forced to feed in less-profitable habitats and on lessprofitable prey.

The inter-specific comparison including all species was focused on Moëze in winter because it counted the highest number of samples. The shorebird community structure was thus considered as stable and not modified by migrating individuals from other populations. The influence of each functional group of prey on the position of shorebirds' isotopic niches were 
deduced from the comparisons of the positions of their own trophic niche and the trophic enrichment between prey and predator (Kelly, 2000). Four species: Grey Plover, Dunlin, Bartailed Godwit and Curlew were located at the highest trophic levels. It was unexpected that Dunlin, the smaller species of the community was located at the same trophic level as the largest one: the Curlew. Worms are generally the predominant prey of Grey Plover (Cramps and Simmon, 1983), Bar-tailed Godwit (Scheiffarth, 2001; Duijns et al., 2009) and Curlew (Boileau and Delaporte, 2012). At Moëze, worms are at the highest trophic level among mudflat macro-invertebrates. Therefore, it is likely that a diet based on worms would result in high trophic level in the predators. Dunlin, Bar-tailed Godwit and Curlew can probe the mud when foraging but with different depth abilities according to the size of their bill. Dunlins can reach a maximum depth of c. $4 \mathrm{~cm}$ while bar-tailed godwits can probe through a maximum depth of c. $11 \mathrm{~mm}$ and curlews to c. $17 \mathrm{~cm}$ (Table 1). Grey Plover has a very short bill compared to his mean body mass and chase visually on the mud surface. Consequently, even if they feed on the same category of prey, they do not have the same abilities to catch the same size of worms and possibly not the same species either.

Between the four species, the Dunlin had the largest size of the isotopic niche which is probably explained by a more generalist diet than the others species (Dierschke et al., 1999). Therefore, this strictly marine diet only concerned a part of the sampled dunlins (CALALP2). Others individuals (CALALP1) displayed different behaviours with isotopic signatures in blood approaching terrestrial signatures of potential sources. These individuals, caught during the entire winter period, complemented their marine prey by terrestrial ones in marshes (place of catching). However, some of them probably feed mostly in marshes as they do at Ria de Aveiro in Portugal (Luis et al., 2002). 
The diet of red knots and black-tailed godwits were previously studied by faeces analyses in Moëze and both species were described as strictly molluscivorous. Red knots preyed mainly on the very abundant gastropod Hydrobia ulvae in winter (Quaintenne et al., 2010) and blacktailed godwits ingested mostly the bivalve Macoma balthica ignoring other species (Robin et al., 2013). These diets on deposit or deposit-suspensivorous molluscs explain the lower trophic position of both species and the observed differences with the guild of worm-eaters. The larger variability in $\delta^{15} \mathrm{~N}$ signatures noticed for godwits could be due to their larger prospecting/feeding area including the edging mudflats of the Charente Estuary located between Yves and Moëze dwelling $M$. balthica from with higher $\delta^{15} \mathrm{~N}$ values due to higher enrichment by the river discharges.

The Oystercatcher and the Redshank showed no significant differences of their mean signatures while the isotopic niche of Redshank was much larger with high variability of the signatures. Oystercatchers are fairly rare in Moëze because of the muddy character of intertidal area. The position of isotopic signatures and the narrowness of the isotopic niche compared to the other species suggest that they feed mainly on two of their usual prey: the cockle Cerastoderma edule (Blomert et al., 1996) and the clam Ruditapes philippinarum (Caldow et al., 2007), even if signatures of these species were provided from Moëze and not from Yves. The Oystercatcher is the only species of the eight studied species that is able to feed on large size suspensivorous molluscs thanks to its hammered bill (Swennen et al., 1983).

It is not very likely that redshanks feed mostly on cockles and clams as do oystercatchers. In Europe, their diet on intertidal mudflats is composed of a large variety of prey (Goss-Custard and Jones, 1976) but they can seasonally shift on other feeding habitats like marshes or saltworks (Masero and Pérez-Hutardo, 2001; Sánchez et al., 2005). Consequently the high 
variability of signatures for this species and the mean position of the isotopic values between marine and terrestrial prey could indicate that individuals have different feeding strategies in the area between marshes and mudflats or/and they feed on a wide variety of prey in each of the habitats. The Redshank appears as the most generalist species with the highest variety of prey collected and feeding habitats visited.

In this study, we did not detect direct ingestion of biofilm by dunlins as noticed for the species in some sites on the Pacific coast (Kuwae et al., 2012). Most of species specialized in biofilm feeding are among the smallest species of shorebirds like the Western Sandpiper Calidris maurii (Kuwae et al., 2008) or Semipalmated Sandpiper Calidris pusilla (mac Donald et al. 2012) restricted to north and south Americas. These sandpipers are equipped with an unique tongue papillae, and the keratinized lateral spines along the edges and at the tips of the western sandpiper tongue are markedly longer and denser than for those of the dunlin to ingest biofilm from the mud surface (Elner et al. 2005). But the species from this group are relatively rare in Western Europe or only present for short period during spring and autumn migration. Nevertheless, the biofilm occupied a central position in the trophic web of intertidal mudflat and constitute the food for most of the macrofaunal species like Hydrobia ulvae (Pascal et al. 2008), Macoma balthica (van Colen et al. 2010a, van Colen et al. 2010b) or Nereis diversicolor (Colen et al. 2010b, Rossi and Middelburg, 2011) and highly probably Neanthes succinea as indicated in figure 3. These species constitute the bulk of prey for most of the avian predator foraging on mudflat.

In conclusion, the stable isotope analyses in this study have yielded several unique insights into the foraging ecology of this guild of shorebirds. Four groups of shorebirds can be discriminated inside the community and outside ecomorphological patterns considerations: four species were predominantly worm-eaters (Grey Plover, Bar-tailed-Godwit, Curlew and a 
majority of the dunlins), two species were predominantly depositit-suspensivorous mollusceaters (Red Knot and Black-tailed Godwit), one species was predominantly suspensivorous mollusc-eater (Oystercatcher) and two species adopted opportunistic behaviours feeding on mudflat and/or in marshes (Redshank and a fraction of the dunlins).

Inside these trophic groups, resource partitioning could be due to several factors despite overlap in prey choices. Species could be distributed differently on the intertidal area with larger species possibly excluding smaller ones from the most profitable feeding areas. Common resource can be shared according to prey size selection. In any case, if resources are sufficiently abundant and not limiting, then competition between species does not occur and prey selection is only made according to the morphological and physiological characteristics of each species. For shorebirds, analyzing stable isotope values in whole blood appears to be a reliable method for investigating food and feeding ecology during the entire non breeding period and to directly compare species with a less time consuming method. However, the method is at its most powerful when combined with other conventional (feces or stomach content analysis) and non-conventional (bio-logging) approaches. This study is not only important from an ecological point of view but also has pertinent implications for the conservation of these species. The narrow trophic niches of some shorebird species in the study area and their dependence on a limited number of prey species could make them highly vulnerable to the reduction of invertebrate stocks.

\section{Acknowledgements}

This work was sponsored by the French National Research Agency (ANR) through the VASIREMI project "Trophic significance of microbial biofilms in tidal flats" (Contract No. ANR- 06-BLAN-0393-01).The authors wish to thank the Natural Reserves of the Pertuis Charentais (Moëze-Oléron, Marais d'Yves and Lilleau des Niges) for their participation and 
technical assistance during bird catches. We especially thank J. Gautier and J. Gonin from the Moëze-Oléron Natural Reserve for the catches management. We thank G. Quaintenne for field participation. We thank C. Fontaine (UMR LIENSs) for feathers and blood sample preparation for isotopic analysis. We also thank P. Richard and G. Guillou (UMR LIENSs) for technical support during stable isotope analysis.

\section{References}

Aguilera, M.A., Navarrete, S.A., 2011. Distribution and activity patterns in an intertidal grazer assemblage: influence of temporal and spatial organization on interspecific associations. Mar. Ecol. Prog. Ser. 431, 119-136.

Atkinson, P.W., Baker, A.J., Bevan, R.M., Clark, N.A., Cole, K.B., Gonzalez, P.M., Newton, J., Niles, L.J., Robinson, R.A., 2005. Unravelling the migration and moult strategies of a long-distance migrant using stable isotopes: Red Knot Calidris canutus movements in the Americas. Ibis 147, 738-749.

Baker, M.C., Baker, A.E.M., 1973. Niche Relationships Among Six Species of Shorebirds on Their Wintering and Breeding Ranges. Ecol. Monogr. 43, 193-212.

Bearhop, S., Phillips, R.A., McGill, R., Cherel, Y., Dawson, D.A., Croxall, J.P., 2006. Stable isotopes indicate sex-specific and long-term individual foraging specialisation in diving seabirds. Mar. Ecol. Prog. Ser. 311, 157-164.

Blomert, A.-M., Ens, B.J., Goss-Custard, J.D., Hulscher, J.B., Zwarts, L., 1996. Oystercatchers and their estuarine food supplies. Ardea 84A. Nederlandsche Ornithologische Unie, Amsterdam.

Bocher, P., Piersma, T., Dekinga, A., Kraan, C., Yates, M., Guyot, T., Folmer, E., Radenac, G., 2007. Site- and species- specific distribution patterns of molluscs at five intertidal softsediment areas in northwest Europe during a single winter. Mar. Biol. 151, 577-594.

Bocher, P., Quaintenne, G., Robin, F., Doumeret, A., Delaporte, P., 2012. Origins and age structure of Red Knots Calidris canutus staging and wintering on the Atlantic coast of France. J. of Ornith. 153, 103-114.

Boileau, N., Delaporte, P., 2012. Sex related differences in feeding behaviour of the Eurasian Curlew Numenius arquata in winter. Alauda 80, 13-21.

Burger, J., Caldwell, H., D., Chase, J., 1979. Aggressive interactions in mixed-species flocks of migrating shorebirds. Anim. Behav. 27, 459-469.

Caillot E., Elder J. F. 2000-2010. Synthèses annuelles, dénombrements mensuels des limicoles côtiers. Observatoire des limicoles côtiers, RNF.

Caldow, R.W.G., Stillman, R.A., Durell, S.E.A.l.V.d., West, A.D., Mc Grorty, S., GossCustard, J.D., Wood, P.J., Humphreys, J., 2007. Benefits to shorebirds from invasion of a non-native shellfish. Proc. Roy. Soc. B: Biol. Sci. 274, 1449-1455. 
Cherel, Y., Le Corre, M., Jaquemet, S., Menard, F., Richard, P., Weimerskirch, H., 2008. Resource partitioning within a tropical seabird community: new information from stable isotopes. Mar. Ecol. Progr. Ser. 366, 281-291.

Colwell, M.A., 1993. Shorebird community patterns in a seasonally dynamic estuary. The Condor 95, 104-114.

Colwell, M.A., 2010. Shorebird Ecology, Conservation, and Management. University of California Press, Berkeley, Los angeles.

Cramp, S., Simmons, K.E.L., 1983. Handbook of the birds of Europe, the Middle East, and North Africa. Vol. III. Waders to Gulls. Oxford University Press, Oxford

de Boer, W.F., 2002. The shorebird community structure at an intertidal mudflat in southern Mozambique. Ardea 90, 81-92.

De Niro, M.L., Epstein, S., 1978. Influence of diet on the distribution of carbon isotopes in animals. Geochim. Cosmochim. Acta 42, 495-506.

Delany, S., Scott, D., Dodman, T., Stroud, D.A., 2009. An atlas of wader populations in Africa and western Eurasia. Wetlands International, Wageningen, The netherlands.

Dierschke, V., Kube, J., Rippe, H., 1999. Feeding ecology of dunlins Calidris alpina staging in the southern Baltic Sea, 2. Spatial and temporal variations in the harvestable fraction of their favourite prey Hediste diversicolor. J. of Sea Res. 42, 65-82.

Duijns, S., van Dijk, J.G.B., Spaans, B., Jukema, J., De Boer, W.F., Piersma, T., 2009. Foraging site selection of two subspecies of Bar-tailed Godwit limosa lapponica: time minimizers accept greater predation danger than energy minimizers. Ardea 97, 51-59.

Durell, S.E.A.L.V.D., 2000. Individual feeding specialisation in shorebirds: population consequences and conservation implications. Biol. Rev. 75, 503-518.

Elner, R., Beninger, P., Jackson, D., Potter, T., 2005. Evidence of a new feeding mode in western sandpiper (Calidris mauri) and dunlin (Calidris alpina) based on bill and tongue morphology and ultrastructure. Mar. Biol. 146, 1223-1234.

Fasola, M., Canova, L., Biddau, L., 1996. Foraging habits of crab plovers Dromas ardeola overwintering on the Kenya coast .Col. Waterbirds 19, 207-213.

Forero, M.G., Bortolotti, G.R., Hobson, K.A., Donazar, J.A., Bertelloti, M., Blanco, G., 2004. High trophic overlap within the seabird community of Argentinean Patagonia: a multiscale approach. J. of Anim. Ecol. 73, 789-801.

Fussmann, G.F., Heber, G., 2002. Food web complexity and chaotic population dynamics. Ecol. Lett. 5, 394-401. 
Goss-Custard, J.D., Durell, S.E.A.L.E.V.D., 1983. Individual and age differences in the feeding ecology of Oystercatchers Haematopus ostralegus wintering on the Exe Estuary, Devon. Ibis 125, 155-171.

Goss-Custard, J.D., Jones, R.E., 1976. The Diets of Redshank and Curlew. Bird Stud. 23, 233-243.

Hobson, K.A., Clark, R.G., 1992. Assessing avian diets using stable isotopes I: turnover of 13C in tissues. The Condor 94, 181-188.

Jaeger, A., Connan, M., Richard, P., Cherel, Y., 2010. Use of stable isotopes to quantify seasonal changes of trophic niche and levels of population and individual specialisation in seabirds. Mar. Ecol. Progr. Ser. 401, 269-277.

Jing, K., Ma, Z., Li, B., Li, J., Chen, J., 2007. Foraging strategies involved in habitat use of shorebirds at the intertidal area of Chongming Dongtan, China. Ecol. Res. 22, 559-570.

Kelly, J.F., 2000. Stable isotopes of carbon and nitrogen in the study of avian and mammalian trophic ecology. Can. J. of Zool. 78, 1-27.

Kojadinovic, J., Ménard, F., Bustamante, P., Cosson, R.P., LeCorre, M., 2008. Trophic ecology of marine birds and pelagic fishes from Reunion Island as determined by stable isotope analysis. Mar. Ecol. Progr. Ser. 361, 239-251.

Kuwae, T., Beninger, P. G., Decottignies, P., Mathot, K. J., Lund, D. R. \& Elner, R. W. 2008. Biofilm grazing in a higher vertebrate: the western sandpiper, Calidris mauri. Ecology, 89: 599-606.

Kuwae, T., Miyoshi, E., Hosokawa, S., Ichimi, K., Hosoya, J., Amano, T., Moriya, T., Kondoh, M., Ydenberg, R.C., Elner, R.W., 2012. Variable and complex food web structures revealed by exploring missing trophic links between birds and biofilm. Ecol. Lett. 15, 347356.

Layman, C.A., Arrington, D.A., Montaña, C.G., Post, D.M., 2007. Can stable isotope ratios provide for community-wide measures of trophic structure? Ecology 88, 42-48.

Layman, C.A., Araujo, M.S., Boucek, R., Hammerschlag-Peyer, C.M., Harrison, E., Jud, Z.R., Matich, P., Rosenblatt, A.E., Vaudo, J.J., Yeager, L.A., Post, D.M., Bearhop, S., 2012. Applying stable isotopes to examine food-web structure: an overview of analytical tools. Biol. Rev. 87, 545-562.

Lopes, R.J., Múrias, T., Cabral, J.A., Marques, J.C., 2005. A Ten Year Study of Variation, Trends and Seasonality of a Shorebird Community in the Mondego Estuary, Portugal. Waterbirds 28, 8-18. 
Luís, A., Goss-Custard, J.D., Moreira, M.H., 2002. The feeding strategy of the dunlin (Calidris alpina L.) in artificial and non-artificial habitats at Ria de Aveiro, Portugal. Hydrobiol. 475-476, 335-343.

MacDonald, E. C., Ginn, M. G. \& Hamilton, D. J. 2012. Variability in foraging behavior and implications for diet breadth among Semipalmated sandpipers staging in the upper Bay of Fundy. The Condor, 114: 135-144

Mahéo, R., 2011. Limicoles séjournant en France (Littoral). Wetland International-Office national de la Chasse et de la Faune Sauvage, p. 49.

Masero, J.A., Perez-Hutardo, A., 2001. Importance of the supratidal habitats for maintaining overwintering shorebird populations: how redshanks use tidal mudflats and adjacent saltworks in Southern Europe. The Condor 103, 21-30.

Meire, P., Schekkerman, H., Meininger, P., 1994. Consumption of benthic invertebrates by waterbirds in the Oosterschelde estuary, SW Netherlands. Hydrobiol. 282-283, 525-546.

Metcalfe, N.B., 1989. Flocking Preferences in Relation to Vigilance Benefits and Aggression Costs in Mixed-Species Shorebird Flocks. Oikos 56, 91-98.

Myers, R.A., Worm, B., 2003. Rapid worldwide depletion of predatory fish communities. Nature Publishing Group, London.

Nebel, S., Jackson, D.L., Elner, R.W., 2005. Functional association of bill morphology and foraging behaviour in calidrid sandpipers. Anim. Biol. 55, 235-243.

Nebel, S., Thompson, G.J., 2011. The evolution of sexual bill-size dimorphism in shorebirds: a morphometric test of the resource partitioning hypothesis. Evol. Ecol. Res. 13, 35-44.

Ogden, L.J.E., Hobson, K.A., Lank, D.B., Martínez del Rio, C., 2004. Blood isotopic ( $\delta 13 \mathrm{C}$ and $\delta 15 \mathrm{~N}$ ) turnover and diet-tissue fractionation factors in captive dunlin (Calidris alpina pacifica). The Auk 121, 170-177.

Paine, R., T., 1980. Food Webs: Linkage, Interaction Strength and Community Infrastructure. J. of Anim. Ecol. 49, 666-685.

Pascal, P.-Y., Dupuy, C., Richard, P., Haubois, A.-G. \& Niquil, N. 2008. Influence of environment factors on bacterial ingestion rate of the deposit-feeder Hydrobia ulvae and comparison with meiofauna. Journal of Sea Research, 60: 151-156.

Phillips, R.A., McGill, R.A.R., Dawson, D.A., Bearhop, S., 2011. Sexual segregation in distribution, diet and trophic level of seabirds: insights from stable isotope analysis. Mar. Biol. 158, 2199-2208.

Piersma, T., van Gils, J.A., 2011. The Flexible Phenotype: A Body-Centred Integration of Ecology, Physiology, and Behavior. Oxford University Press, Oxford. 
Puttick, G.M., 1978. The diet of the curlew sandpiper at Langebaan Lagoon, South Africa. Ostrich 49, 158-167.

Quaintenne, G., van Gils, J.A., Bocher, P., Dekinga, A., Piersma, T., 2010. Diet selection in a molluscivore shorebird across Western Europe: do they show short- or long-term intake ratemaximization? J. of Anim. Ecol. 79, 53-62.

Robin, F., Piersma, T., Meunier, F., Bocher, P., 2013. Expanding into a herbivorous niche by a customary carnivore: Zostera-rhizome feeding by black-tailed godwits at a newly established wintering site. The Condor in press.

Rossi, F. \& Middelburg, J. J. 2011. Intraspecific diet shift of Macoma balthica during community reassembly in an estuarine intertidal flat. Estuar., Coast and Shelf Sci, 92: 496501.

Sánchez, M.I., Green, A.J., Castellanos, E.M., 2005. Seasonal variation in the diet of Redshank Tringa totanus in the Odiel Marshes, southwest Spain: a comparison of faecal and pellet analysis: Capsule Redshank diet from southern Europe during migration shows spatial and seasonal variations. Bird Study 52, 210-216.

Scheiffarth, G., 2001. The diet of bar-tailed godwits Limosa lapponica in the Wadden sea: combining visual observations and faeces analyses. Ardea 89, 481-494.

Swennen, C., De Bruijn, L.L.M., Duiven, P., Leopold, M.F., Marteijn, E.C.L., 1983. Differences in bill form of the oystercatcher Haematopus ostralegus; a dynamic adaptation to specific foraging techniques. J. of Sea Res. 17, 57-83.

Turner, T.F., Collyer, M.L., Krabbenhoft, T.J., 2010. A general hypothesis-testing framework for stable isotope ratios in ecological studies. Ecology 91, 2227-2233.

van Colen, C., De Backer, A., Meulepas, G., van der Wal, D., Vincx, M., Degraer, S., Ysebaert, T. 2010a. Diversity, trait displacements and shifts in assemblage structure of tidal flat deposit feeders along a gradient of hydrodynamic stress. Mar. Ecol. Prog. Ser. 406: 79-89

van Colen, C., Montserrat, F., Vincx, M., Herman, P.M.J., Ysebaert, T., Degraer, S. 2010b. Macrobenthos recruitment success in a tidal flat: Feeding trait dependent effects of disturbance history. J. Exp. Mar. Biol. and Ecol. 385, 79-84

van de Kam, J., Ens, B.J., Piersma, T., Zwarts, L., 2004. Shorebirds. An illustrated behavioural ecology. KNNV Publishers, Utrecht, The Netherlands.

Werner, E.E., Gilliam, J.F., 1984. The Ontogenetic Niche and Species Interactions in SizeStructured Populations. Ann. Rev. of Ecol. and Syst. 15, 393-425.

Yates, M.G., Goss-Custard, J.D., McGrorty, S., Lakhani, K.H., Le V. Dit Durell, S.E.A., Clarke, R.T., Rispin, W.E., Moy, I., Yates, T., Plant, R.A., Frost, A.J., 1993. Sediment 
characteristics, invertebrate densities and shorebird densities on the inner banks of the Wash. J. of Appl. Ecol. 30, 599-614.

Zwarts, L., Wanink, J.H., 1993. How the food supply harvestable by waders in the Wadden Sea depends on the variation in energy density, body weight, biomass, burying depth and behaviour of tidal-flat invertebrates. J. of Sea Res. 31, 441-476. 


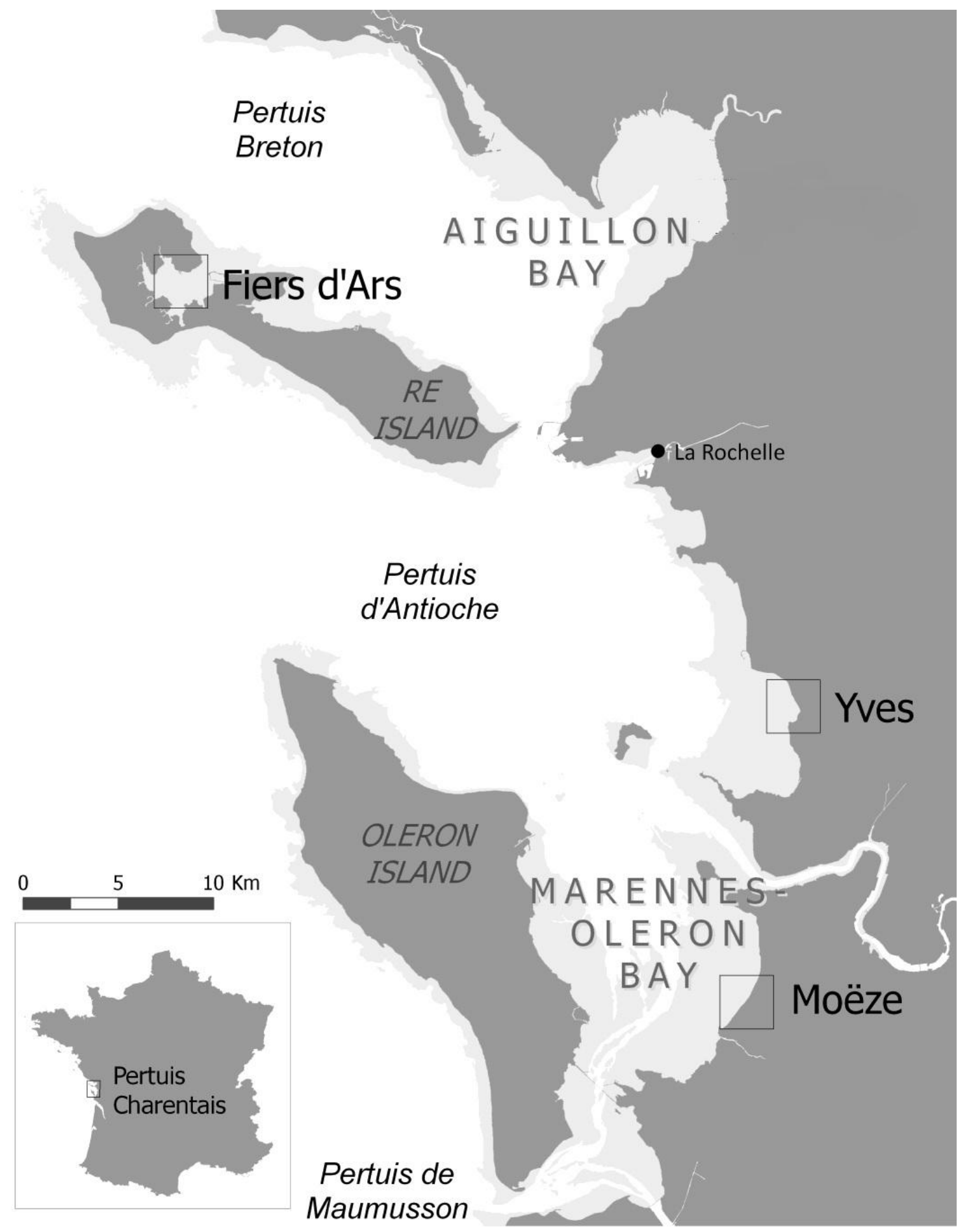

Figure 1. Location of the Pertuis Charentais in France and location of the three study sites in the Pertuis Charentais area. 

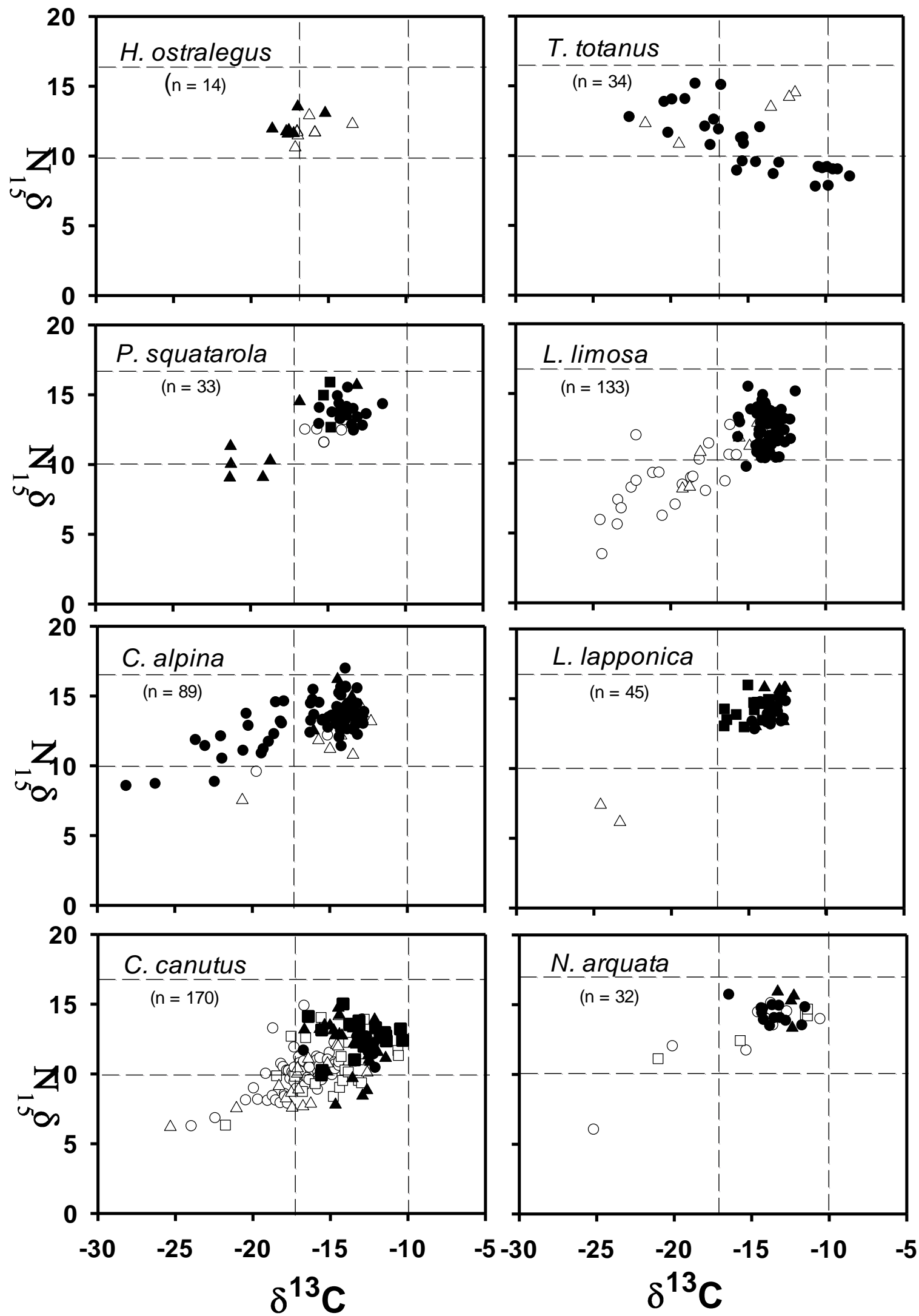

Figure 2. Stable carbon and nitrogen isotope values of blood per individuals of the eight shorebird species in autumn (white dot) and in winter (black dot); and for the three sites: 
Moëze (Circle), Yves (triangle) and Ré Island (square). The gridlines prefigure the limit values in adult individuals for most of the species

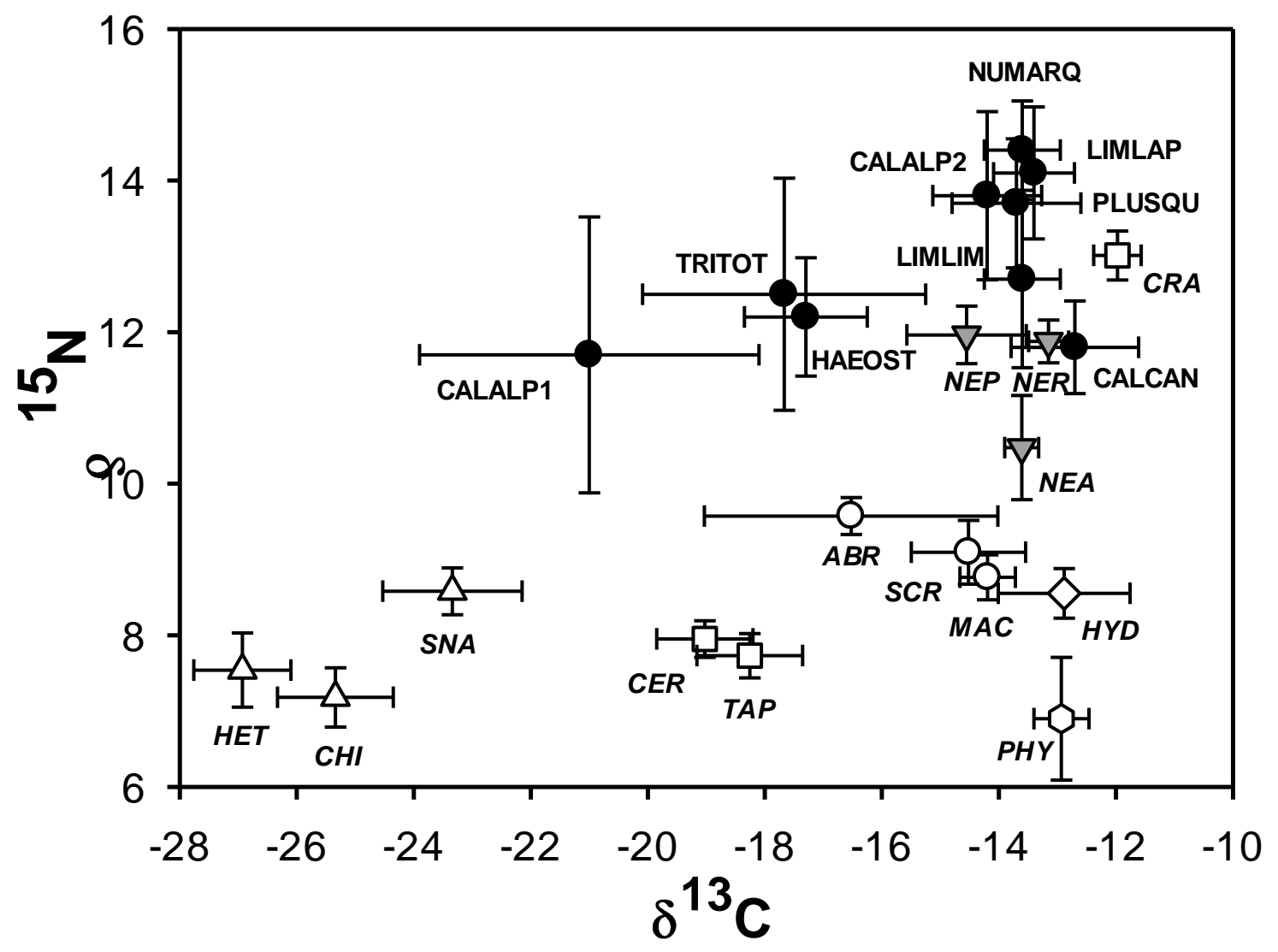

Figure 3. Stable carbon and nitrogen isotope values of blood of birds caught in winter in Moëze (except Haematopus ostralegus, caught in Yves) and of potential prey species in marshes (3 species) and mudflat (10 species) in Moëze area. Values are means \pm SD. For abbreviations refer to Table 2. Birds, annelids, crustacean, gastropods, phytobenthos and terrestrial invertebrates were distinguished by different symbols. For bivalves, suspensivores (Cerastoderma edule and Ruditapes philippinarum) and deposivores-suspensivores (Macoma balthica, Scrobicularia plana and Abra tenuis) species were distinguished by different symbols. 

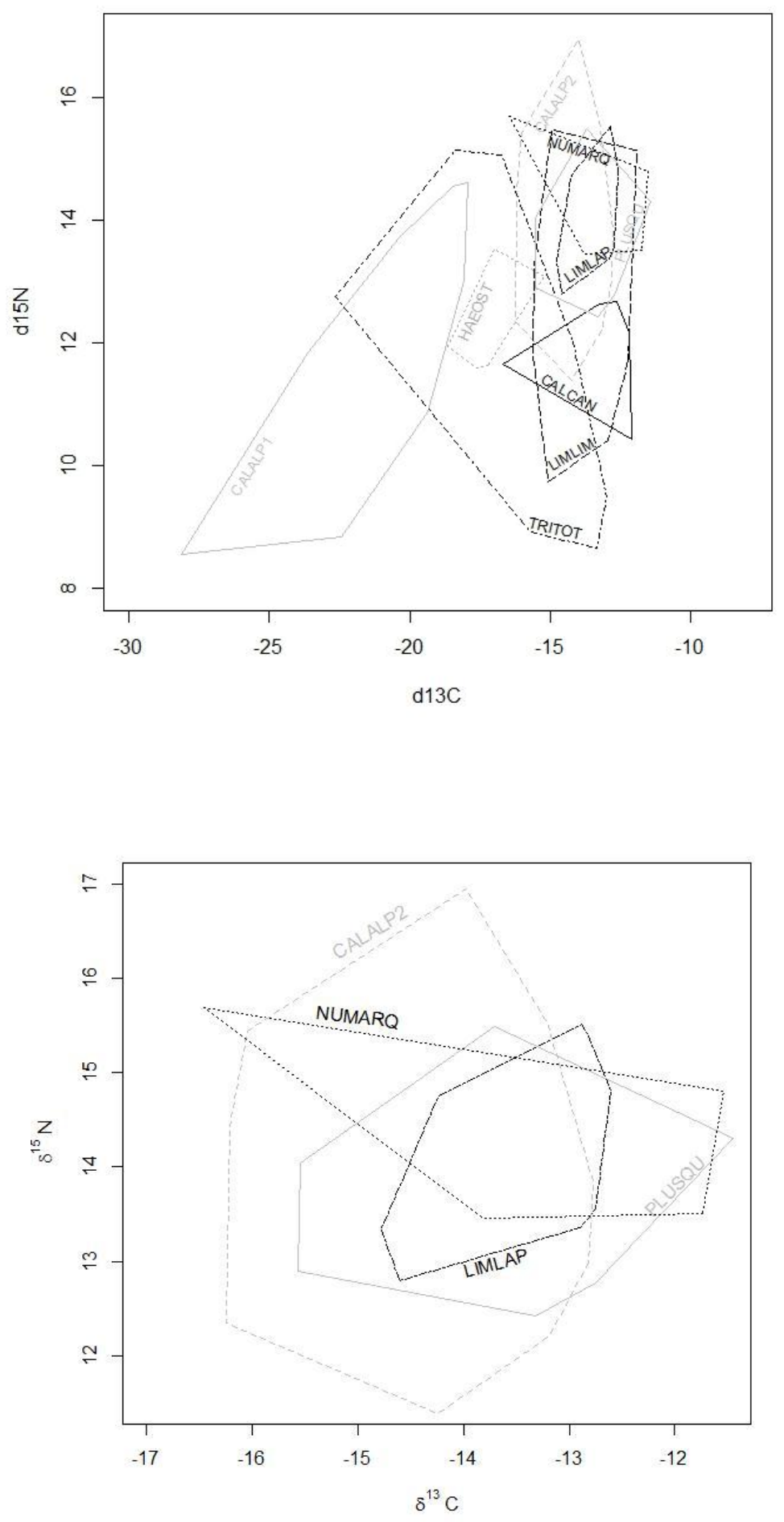

Figure 4. Polygons encompassing the convex hull area for each shorebird species in Moëze in winter (except Haematopus ostralegus in Yves) in $\delta^{13} \mathrm{C}-\delta^{15} \mathrm{~N}$ niche space (a) and magnification for the four species with high overlap (b). For abbreviations refer to Table 1. 
Table 1. Mean body mass and bill length of shorebirds per species with the number of blood samples collected per season or per age within each site.

\begin{tabular}{|c|c|c|c|c|c|c|c|c|c|c|c|c|c|}
\hline \multirow{3}{*}{ Species } & \multirow{3}{*}{ ACRONYM } & \multicolumn{2}{|c|}{ Biometrics characteristics } & \multicolumn{2}{|c|}{$\begin{array}{l}\text { Blood samples per } \\
\text { season }\end{array}$} & \multicolumn{6}{|c|}{ Blood samples per site (n) } & \multicolumn{2}{|c|}{$\begin{array}{l}\text { Blood samples } \\
\text { per species (n) }\end{array}$} \\
\hline & & \multirow{2}{*}{$\begin{array}{l}\text { Body Mass } \\
\text { Mean } \pm \text { SD (min-max)g }\end{array}$} & \multirow{2}{*}{$\begin{array}{l}\text { Bill length } \\
\text { Mean } \pm \text { SD (min-max) } \\
\text { mm }\end{array}$} & \multirow[b]{2}{*}{$\begin{array}{l}\text { Autumn } \\
\text { (n) }\end{array}$} & \multirow[b]{2}{*}{$\begin{array}{l}\text { Winter } \\
\text { (n) }\end{array}$} & \multicolumn{2}{|c|}{ Moëze } & \multicolumn{2}{|c|}{ Yves } & \multicolumn{2}{|l|}{ Ré } & \multirow[b]{2}{*}{$\begin{array}{l}\text { Total } \\
\text { (n) }\end{array}$} & \multirow[b]{2}{*}{$\begin{array}{l}\text { Juv } \\
(\%)\end{array}$} \\
\hline & & & & & & $\begin{array}{l}\mathrm{Ad} \\
\text { (n) }\end{array}$ & $\begin{array}{l}\text { Juv } \\
\text { (n) }\end{array}$ & $\begin{array}{l}\mathrm{Ad} \\
\text { (n) }\end{array}$ & $\begin{array}{l}\text { Juv } \\
\text { (n) }\end{array}$ & $\begin{array}{l}\mathrm{Ad} \\
(\mathrm{n})\end{array}$ & $\begin{array}{l}\text { Juv } \\
\text { (n) }\end{array}$ & & \\
\hline \multicolumn{2}{|c|}{ Haematopus ostralegus НАЕОSт } & $512 \pm 56(455-685)$ & $75.3 \pm 5.6(66-85)$ & 7 & 7 & - & - & 14 & - & - & - & 14 & 0 \\
\hline Pluvialis squatarola & PLUSQU & $210 \pm 26(160-320)$ & $29.2 \pm 1.5(26-32)$ & 6 & 27 & 20 & 1 & 1 & 6 & 5 & - & 33 & 21 \\
\hline Calidris canutus & CALCAN & $129 \pm 14(87-185)$ & $33.6 \pm 2.6(26-47)$ & 106 & 64 & 15 & 67 & 10 & 34 & 7 & 37 & 170 & 81 \\
\hline Calidris alpina & CALALP & $46 \pm 5(36-60)$ & $33.0 \pm 3.3(23-39)$ & 12 & 77 & 49 & 29 & 3 & 8 & - & - & 89 & 42 \\
\hline Tringa totanus & тRITOT & $122 \pm 12(96-140)$ & $42.4 \pm 2.6(37-50)$ & 5 & 29 & 28 & 1 & 3 & 2 & - & - & 34 & 9 \\
\hline Limosa limosa & цімLім & $295 \pm 36(215-374)$ & $87.5 \pm 8.4(74-108)$ & 32 & 101 & 24 & 98 & 7 & 4 & - & - & 133 & 77 \\
\hline Limosa lapponica & LIMLAP & $271 \pm 39(180-340)$ & $84.4 \pm 13.1(55-109)$ & 9 & 36 & 2 & 15 & 3 & 7 & 8 & 10 & 45 & 71 \\
\hline Numenius arquata & NUMARQ & $754 \pm 109(540-995)$ & $127.6 \pm 17.0(101-165)$ & 15 & 17 & 18 & 5 & 4 & - & 3 & 2 & 32 & 22 \\
\hline
\end{tabular}


Table 2. Results of nested PERMANOVAs for the effects of situations on values of Carbon and Nitrogen isotopic signatures. Data were square-root transformed prior to analysis. Species were nested in site for analysis (Species*site). Results of a Bartlett test are presented for relevant pairwise comparisons, if $\mathrm{p}$-values were non or less significant in a PERMANOVA.

\begin{tabular}{|c|c|c|c|c|c|c|c|c|}
\hline \multirow[b]{2}{*}{ Isotope } & \multirow[b]{2}{*}{ Variable } & \multicolumn{4}{|c|}{ PERMANOVA } & \multicolumn{3}{|c|}{ Post-hoc Bartlett test } \\
\hline & & $F_{1.82}$ & $\overline{\mathbf{R}^{2}}$ & $\mathbf{P}$ & & K-square & $\mathbf{P}$ & \\
\hline \multirow[t]{10}{*}{$\delta^{13} \mathrm{C}$} & Species & 28.760 & 0.179 & 0.001 & $* * *$ & & & \\
\hline & Age & 45.531 & 0.032 & 0.001 & $* * *$ & & & \\
\hline & Season & 216.534 & 0.164 & 0.001 & $* * *$ & & & \\
\hline & Species*Site & 7.133 & 0.705 & 0.001 & $* * *$ & & & \\
\hline & Season x Age & 7.756 & 0.006 & 0.003 & $* *$ & 10.787 & 0.013 & $*$ \\
\hline & Season $\mathrm{x}$ Species & 14.434 & 0.077 & 0.001 & $* * *$ & & & \\
\hline & Season x Species*Site & 5.279 & 0.024 & 0.001 & $* * *$ & & & \\
\hline & Age $x$ Species & 7.591 & 0.040 & 0.001 & $* * *$ & & & \\
\hline & Age x Species*Site & 3.078 & 0.023 & 0.005 & $* *$ & 175.368 & 0.001 & $* * *$ \\
\hline & Season x Age x Species & 4.665 & 0.014 & 0.004 & $* *$ & 313.712 & 0.001 & $* * *$ \\
\hline \multirow[t]{10}{*}{$\delta^{15} \mathrm{~N}$} & Species & 43.938 & 0.265 & 0.001 & $* * *$ & & & \\
\hline & Age & 85.593 & 0.064 & 0.001 & $* * *$ & & & \\
\hline & Season & 178.340 & 0.134 & 0.001 & $* * *$ & & & \\
\hline & Species*Site & 6.563 & 0.064 & 0.001 & $* * *$ & & & \\
\hline & Season $x$ Age & 11.499 & 0.008 & 0.002 & $* *$ & 10.103 & 0.017 & $* * *$ \\
\hline & Season $\mathrm{x}$ Species & 6.353 & 0.033 & 0.001 & $* * *$ & & & \\
\hline & Season $x$ Species*Site & 3.467 & 0.016 & 0.003 & $* *$ & 104.786 & 0.001 & $* * *$ \\
\hline & Age x Species & 3.428 & 0.018 & 0.001 & $* * *$ & & & \\
\hline & Age x Species*Site & 1.533 & 0.012 & 0.136 & & 120.704 & 0.001 & $* * *$ \\
\hline & Season x Age x Species & 4.468 & 0.013 & 0.002 & $* *$ & 109.742 & 0.001 & $* * *$ \\
\hline
\end{tabular}




\section{Appendix}

Table A. Mean stable carbon and nitrogen isotope values ( \pm SD) of blood in winter in Moëze of the eight shorebird species (except for Haematopus ostralegus, caught in Yves) of potential prey species in marshes (3 species) and mudflat (10 species) in Moëze area in February 2008.

\begin{tabular}{lllll}
\hline Species & Acronym & $\mathrm{n}$ & $\delta^{15} \mathrm{C}(\%)$ & $\delta^{13} \mathrm{~N}(\%)$ \\
\hline Shorebirds & & & & \\
\multicolumn{1}{l}{ Haematopus ostralegus } & HAEOST & 7 & $-17.29 \pm 1.09$ & $12.20 \pm 0.78$ \\
Pluvialis squatarola & PLUSQU & 15 & $-13.73 \pm 1.05$ & $13.73 \pm 0.78$ \\
Calidris canutus & CALCAN & 17 & $-12.74 \pm 1.09$ & $11.82 \pm 0.61$ \\
Calidris alpina & CALALP1 & 18 & $-20.97 \pm 2.90$ & $11.71 \pm 1.82$ \\
& CALALP2 & 55 & $-14.24 \pm 0.93$ & $13.82 \pm 1.11$ \\
Tringa totanus & TRITOT & 21 & $-17.18 \pm 0.85$ & $11.55 \pm 2.14$ \\
Limosa limosa & LIMLIM & 100 & $-13.62 \pm 0.65$ & $12.67 \pm 1.17$ \\
Limosa lapponica & LIMLAP & 15 & $-13.45 \pm 0.69$ & $14.12 \pm 0.87$ \\
Numenius arquata & NUMAQU & 13 & $-13.62 \pm 1.25$ & $14.38 \pm 0.65$
\end{tabular}

\section{Molluscs}

Bilvaves

$\begin{array}{lllll}\text { Macoma balthica } & \boldsymbol{M A C} & 7 & -14.19 \pm 0.48 & 8.76 \pm 0.30 \\ \text { Scrobicularia plana } & \boldsymbol{S C R} & 15 & -14.52 \pm 0.98 & 9.10 \pm 0.42 \\ \text { Abra tenuis } & \boldsymbol{A B R} & 4 & -16.53 \pm 2.51 & 9.57 \pm 0.24 \\ \text { Cerastoderma edule } & \boldsymbol{C E R} & 5 & -19.03 \pm 0.82 & 7.95 \pm 0.24 \\ \begin{array}{l}\text { Ruditapes philippinarum } \\ \text { Gastropods }\end{array} & \boldsymbol{T A P} & 4 & -18.26 \pm 0.90 & 7.73 \pm 0.29 \\ \text { Hydrobia ulvae } & \text { HYD } & 6 & -12.88 \pm 1.13 & 8.55 \pm 0.33\end{array}$

\section{Annelids}

Neanthes succinea

$\begin{array}{llll}\boldsymbol{N E A} & 6 & -13.61 \pm 0.29 & 10.48 \pm 0.69 \\ \boldsymbol{N E P} & 9 & -14.55 \pm 1.02 & 11.96 \pm 0.38 \\ \boldsymbol{N E R} & 4 & -13.15 \pm 0.34 & 11.88 \pm 0.28\end{array}$

Nepthtys hombergii

Nereis diversicolor

NER

CRA

6

$-11.97 \pm 0.41$

$13.01 \pm 0.32$

Microphytobenthos

PHY

3

$-12.93 \pm 0.47$

$6.90 \pm 0.81$

\section{Terrestrial invertebrates}

Chironomus sp.

Heteroptera larvae

Aquatic snail

$\begin{array}{llll}\boldsymbol{C H I} & 3 & -25.34 \pm 0.99 & 7.18 \pm 0.39 \\ \boldsymbol{H E T} & 3 & -26.93 \pm 0.83 & 7.54 \pm 0.49 \\ \boldsymbol{S N A} & 4 & -23.34 \pm 1.19 & 8.58 \pm 0.31\end{array}$

